\title{
LOYALTY \& DISLOYALTY: SEBUAH PANDANGAN KOMPREHENSIF DALAM ANALISA LOYALITAS PELANGGAN
}

\author{
Licen Indahwati Darsono \\ Universitas Katolik Widya Mandala Surabaya
}

\begin{abstract}
Marketer convinced that customer loyalty is a valuable asset for the company. But, in today marketplace managing customer loyalty is a daunting task. An understanding about customer loyalty concept is prerequisite for managing customer loyalty. Customer loyalty concept best understood with the composite approach; behavioral and attitudinal approach. Composite approach could make marketer to find out loyalty category and loyalty stages of the customers, loyalty's antecedent and manage loyalty from that antecedent. Customer satisfaction is an antecedent of customer loyalty. But, some researchers argued that satisfaction and loyalty relationships is not linear. This statement is supported by the fact in the market, satisfied customers still defect, but several dissatisfied customers don't switch. Therefore, analyzing customer loyalty required holistic view about customer loyalty, loyalty concept alone did not give marketer a comprehensive view in customer loyalty analysis. Marketers and researchers must pay attention to disloyalty.
\end{abstract}

Key words: loyalty, disloyalty, satisfaction

\section{PENDAHULUAN}

Pentingnya loyalitas pelanggan dalam pemasaran tidak diragukan lagi. Pemasar sangat mengharapkan dapat mempertahankan pelanggannya dalam jangka panjang, bahkan jika mungkin untuk selamanya. Seorang pelanggan yang loyal akan menjadi aset yang sangat bernilai bagi organisasi. Pelanggan yang loyal akan mengurangi usaha mencari pelanggan baru, memberikan umpan balik positif kepada organisasi. Selain itu, ada keyakinan yang kuat bahwa loyalitas mempunyai hubungan positif dengan profitabilitas (Hallowell, 1996; Rowley dan Dawes, 1999). Reichheld dan Sasser (1990) seperti dikutip oleh Bowen dan Chen (2001: 213) menemukan bahwa "... when a company retains just 5 percent more of its customers, profits increase by 25 percent to 125 percent." Peningkatan profit tersebut berasal dari penurunan biaya pemasaran dan operasional, serta peningkatan penjualan. Pelanggan yang loyal mempunyai kecenderungan lebih rendah untuk berpindah merek, kurang sensitif terhadap harga, membeli lebih sering dan/atau lebih banyak, menjadi strong word of mouth, menciptakan business referrals (Hallowell, 1996; Mittal dan Lassar, 1998; Bowen dan Chen, 2001; Rowley dan Dawes, 2000).

Lingkungan yang berubah cepat membuat tugas pemasar untuk menciptakan pelanggan yang loyal tidak mudah. Perubahan kondisi perekonomian dan teknologi beserta trend-nya akan berpengaruh pada konsumen dan perilakunya. Perubahan kondisi perekonomian di Indonesia misalnya: (1) dari produksi yang mengandalkan kemajuan teknologi beralih ke kepuasan konsumen yang mengutamakan pelayanan, (2) dari produksi massal ke produksi yang mass customization, (3) dari konsumsi yang menekankan pada kepuasan segera ke konservasi dengan penekanan pada pelestarian lingkungan, pemanfaatan sumber secara efisien, pencegahan polusi, dan pendaur-ulangan, (4) menurunnya daya beli konsumen sejak terjadinya krisis ekonomi tahun 1997. Perubahan teknologi meliputi: (1) dari cara-cara yang bersifat mekanis ke elektronis, terkomputerisasi, (2) dari cara-cara yang bersifat personal ke non-personal, (3) dari material yang berat ke material yang ringan, (4) dari kerangka waktu yang panjang ke kerangka waktu yang pendek. Semua perubahan tersebut mengakibatkan tekanan persaingan yang berat, dan mempengaruhi perilaku konsumen. Kecenderungan pola perilaku konsumen di masa mendatang diperkirakan akan meliputi 3 hal: (1) konsumen mempunyai perhatian yang lebih besar terhadap kualitas dan nilai, (2) waktu akan menjadi sangat berharga 
bagi konsumen, (3) kesadaran konsumen terhadap harga semakin besar (Dharmmesta, 1994; Dharmmesta, 1999).

Pola perilaku konsumen yang demikian menyebabkan kecenderungan konsumen untuk berpindah merek menjadi lebih tinggi, karena konsumen termotivasi untuk mencari alternatif yang lebih baik. Hal ini berarti tugas pemasar mengelola loyalitas pelanggan menjadi semakin rumit dan kompleks, pemasar juga harus bersiapsiap dengan terjadinya perubahan loyalitas pelanggan (Dharmmesta, 1999; Rowley dan Dawes, 2000).

Loyalitas pelanggan mencerminkan loyalitas pelanggan terhadap obyek tertentu. Obyek tersebut dapat berupa merek, produk, atau service outlet tertentu (Rowley dan Dawes, 1999). Dowling dan Uncles (1997) seperti yang dikutip oleh Rowley \& Dawes (1999: 347) menyatakan "Much of the literature on customer loyalty has looked at brand loyalty." Pendapat yang sama dikemukakan oleh Dharmmesta (1999: 75) "Merek dianggap lebih lazim dan lebih banyak menjadi obyek loyal karena dianggap sebagai identitas produk atau perusahaan yang lebih mudah dikenali oleh pelanggan." Oleh karena itu, dalam artikel ini istilah loyalitas pelanggan dan loyalitas merek penggunaannya tidak dibedakan dan dapat diutarakan secara silih berganti.

Penelitian yang dilakukan oleh Hallowel (1996) bahwa "customer satisfaction (kepuasan pelanggan) adalah prasyarat loyalitas pelanggan". Tetapi, fakta di pasar menunjukkan hal yang sebaliknya, kepuasan pelanggan ternyata tidak menjamin pelanggan tersebut tidak berpindah merek; justru sebaliknya pelanggan yang tidak puas tidak berpindah merek (Rowley dan Dawes, 2000). Soderlund (1998) mengemukakan adanya asosiasi positif antara kepuasan pelanggan dan loyalitas pelanggan, dengan catatan peningkatan kepuasan tidak selalu menghasilkan peningkatan loyalitas dalam derajat yang sama. Hal tersebut dibuktikan dengan adanya fakta bahwa pelanggan yang puas pun dapat berpindah merek (Jones \& Sasser, 1995). Studi Mittal dan Lassar (1998) juga menemukan fakta yang sama dengan Jones dan Sasser (1995), bahwa kerentanan berpindah merek selalu disebabkan oleh ketidakpuasan, sedangkan kepuasan tidak selalu menjamin pelanggan untuk loyal. Pelanggan yang puas masih menunjukkân niat untuk berpindah merek. Hal ini menunjukkan hubungan kepuasan pelanggan dan loyalitas pelanggan tidak bersifat linear.

Berdasarkan uraian di atas didapat fakta bahwa pelanggan yang puas masih dapat berganti merek, sebaliknya pelanggan yang tidak puas dan tetap loyal juga banyak ditemukan. Fakta tersebut menunjukkan bahwa "dissatisfaction" (ketidakpuasan) yang selama ini dianggap dapat mengurangi loyalitas, bahkan menimbulkan "disloyalty" (ketidakloyalan) perlu mendapat kajian lebih mendalam. Kajian mendalam tentang ketidakloyalan akan memberikan gambaran yang lengkap dan komprehensif kepada pemasar tentang loyalitas pelanggan. Gambaran yang komprehensif tentang loyalitas akan membantu pemasar untuk mengelola loyalitas pelanggan.

\section{KONSEP LOYALITAS PELANGGAN}

Assael (1998: 130) mendefinisikan loyalitas sebagai "a favorable attitude toward a brand resulting in consistent purchase of the brand over time." Literatur-literatur pemasaran menyatakan bahwa loyalitas dapat dipahami dari dua dimensi sebagai berikut (Jacoby dan Kyner, 1973 seperti dikutip oleh Hallowel, 1996):

1. Loyalty is behavioral, artinya loyalitas dapat dipahami sebagai konsep yang menekankan pada runtutan pembelian, proporsi pembelian, probabilitas pembelian (Dick dan Basu, 1994). Pemahaman ini sering disebut sebagai behavioral approach (pendekatan keperilakuan).

2. Loyalty as an attitude, artinya loyalitas dipahami sebagai komitmen psikologis pelanggan terhadap obyek tertentu (Dharmmesta, 1999). Pemahaman ini sering disebut sebagai attitudinal approach (pendekatan attitudinal).

\section{1. Pendekatan Keperilakuan dan Attitudinal}

Pendekatan keperilakuan mengganggap pembelian yang konsisten atas satu merek tertentu dalam kurun waktu tertentu sebagai indikasi adanya loyalitas. Pemahaman tentang loyalitas dari runtutan pembelian tidak memberikan gambaran tentang loyalitas yang sebenarnya. Alasannya adalah:

- Pengukuran loyalitas berdasarkan perilaku masa lalu dapat memberikan hasil yang keliru, karena runtutan pembelian bukan indikator loyalitas yang sesungguhnya (Assael, 1998). 
- Loyalitas bukan fungsi dari perilaku masa lalu, melainkan fungsi dari proses psikologis (Dharmmesta, 1999)

Jacoby dan Chestnut (1978) seperti yang dikutip oleh Dick dan Basu (1994: 100) mengemukakan kritik atas pendekatan keperilakuan tersebut "...lacking a conceptual basis and capturing only the static outcome of a dynamic process. ... make no attempt to understand the factors underlying repeat purchase." Jadi, pendekatan keperilakuan tidak cukup menjelaskan mengapa dan bagaimana loyalitas merek dibangun dan dikelola.

Keterbatasan pendekatan keperilakuan memunculkan pendekatan baru yang disebut pendekatan attitudinal. Pengukuran loyalitas yang menekankan pada attitude (sikap) sebenarnya lebih penting dan bermanfaat, karena sikap-lah yang akan mendorong perilaku tertentu (Lau dan Lee, 1999). Tetapi, O'Malley (1998) menyatakan bahwa ukuran attitudinal adalah prediktor yang lemah atas perilaku. Ukuran attitudinal meliputi kepuasan, komitmen, dan intention to behave (niat untuk berperilaku). Artinya, pendekatan attitudinal memahami loyalitas sebagai adanya aspek kesukaan dan komitmen terhadap suatu obyek tertentu (Assael, 1998; Dharmmesta, 1999). Ukuran tersebut dikritik tidak cukup kuat memprediksikan perilaku.

Masing-masing pendekatan tersebut di atas tidak memberikan definisi operasional yang memuaskan tentang loyalitas merek. Mowen \& Minor (1998) seperti dikutip oleh Dharmmesta (1999: 74) mengemukakan definisi loyalitas merek sebagai "kondisi dimana konsumen mempunyai sikap positif terhadap sebuah merek, mempunyai komitmen pada merek tersebut, dan bermaksud meneruskan pembeliannya di masa mendatang." Boulding dan kawan-kawan (1993) seperti dikutip oleh Dharmmesta (1999) juga mengemukakan bahwa terjadinya loyalitas merek pada konsumen itu disebabkan oleh adanya pengaruh kepuasan/ketidakpuasan dengan merek tersebut yang terakumulasi secara terus-menerus disamping adanya persepsi tentang kualitas produk. Dua definisi tersebut di atas didasarkan atas pendekatan keperilakuan dan attitudinal. Penggabungan dua pendekatan tersebut baru dapat memberikan definisi operasional yang cukup memuaskan untuk menganalisa loyalitas pelanggan (Dharmmesta, 1999; Dick dan Basu, 1994). Pritchard dan Howard (1997) seperti dikutip oleh Bowen dan Chen (2001: 214) juga mengemukakan pendapat yang sama, "the use of both attitude and behavior in a loyalty definition substantially increases the predictive power of loyalty." Jadi, penggunaan satu ukuran saja dalam mengukur loyalitas mengandung kelemahan-kelemahan, kelemahan ukuran keperilakuan dapat ditutupi oleh ukuran attitudinal, demikian pula sebaliknya.

\section{KATEGORI LOYALITAS}

Loyalitas merek merupakan fenomena attitudinal yang berkorelasi dengan perilaku, atau merupakan fungsi dari proses psikologis (Dharmmesta, 1999). Jacoby dan Chesnut (1978) seperti dikutip oleh Dharmmesta (1999) membedakan 4 macam loyalitas:

1. Loyalitas merek fokal yang sesungguhnya (true focal brand loyalty), loyalitas pada merek tertentu yang menjadi minatnya.

2. Loyalitas merek ganda yang sesungguhnya (true multibrand loyalty), termasuk merek fokal.

3. Pembelian ulang (repeat purchasing) merek fokal dari nonloyal

4. Pembelian secara kebetulan (happenstance purchasing) merek fokal oleh pembeli-pembeli loyal dan nonloyal merek lain.

Pola pembelian ulang dapat mencerminkan loyalitas psikologis seseorang, digambarkan sebagai berikut:

Tabel 1. Kategori loyalitas menurut Jacoby \& Chestnut

\begin{tabular}{|c|c|c|c|c|}
\hline \multirow{2}{*}{$\begin{array}{l}\text { Pembelian ulang } \\
\text { pada }\end{array}$} & \multicolumn{4}{|c|}{ Loyalitas Psikologis pada: } \\
\hline & Merek fokal & Merek ganda & Merek lain & Tidak satupun \\
\hline Merek fokal & $\begin{array}{l}\text { Loyalitas } \\
\text { sesungguhnya }\end{array}$ & Loyal merek ganda & $\begin{array}{l}\text { Pengulang } \\
\text { nonloyal }\end{array}$ & $\begin{array}{l}\text { Pembeli secara } \\
\text { kebetulan }\end{array}$ \\
\hline Merek lain & $\begin{array}{l}\text { Pembeli merek lain } \\
\text { secara kebetulan }\end{array}$ & Loyal merek ganda & Loyal merek lain & $\begin{array}{l}\text { Pembeli secara } \\
\text { kebetulan }\end{array}$ \\
\hline
\end{tabular}

Sumber: Dharmmesta, B.S. (1999) 
Untuk mendeteksi loyalitas merek tunggal yang sesungguhnya, ada 3 hal yang harus diuji, yaitu:

1. Struktur keyakinan (kognitif), artinya informasi merek yang dipegang oleh konsumen (yaitu, keyakinan konsumen) harus menunjuk pada satu merek fokal yang dianggap superior dalam persaingan;

2. Struktur sikap (afektif), artinya tingkat kesukaan konsumen pada merek fokal harus lebih tinggi daripada merek saingan, sehingga ada preferensi afektif yang jelas pada merek fokal;

3. Struktur niat (konatif), artinya konsumen harus mempunyai niat untuk membeli merek fokal, bukannya merek lain, ketika keputusan beli dilakukan (Jacoby dan Chesnut, 1978 seperti dikutip oleh Dharmmesta, 1999).

Tiga hal tersebut mengarah pada dimensi attitudinal, artinya pendapat Jacoby dan Chesnut sejajar dengan pendapat Dick dan Basu (1994), mereka beranggapan bahwa loyalitas itu memerlukan konsistensi dari ketiga struktur psikologis terhadap merek fokal. Perbedaannya terletak pada relative attitude (sikap relatif) yang digunakan Dick dan Basu (1994) dalam mendefinisikan loyalitas. Loyalitas didefinisikan oleh Dick dan Basu (1994: 102) sebagai "Customer loyalty is viewed as the strength of the relationship between individual's relative attitude and repeat patronage." Sikap merepresentasikan asosiasi antara suatu obyek dan evaluasinya. Sikap relatif merupakan tingkat dimana evaluasi konsumen terhadap satu merek mendominasi merek lainnya, jadi yang digunakan skor relatif bukan skor absolut. Alasan yang dikemukakan oleh Dick dan Basu (1994) menggunakan "sikap relatif", bukan "sikap" adalah sikap relatif dapat menjadi indikator yang lebih kuat dari patronase pengulangan, karena menggunakan skor relatif.

Dick dan Basu (1994) mengemukakan dua manfaat dari penggunaan definisi loyalitas tersebut di atas:

1. Mampu menjelaskan variasi-variasi loyalitas yang berasal dari attitudinal dan nonattitudinal sources.

2. Memungkinkan investigasi fenomena-fenomena dari perspektif kausal, sehingga dapat mengidentifikasi anteseden-anteseden yang memfasilitasi konsistensi dan konsekuensi hubungan relative attitude dengan repeat patronage.

Ada dua dimensi yang mendasari tinggi-rendahnya sikap relatif konsumen, yaitu: attitudinal differentiation dan attitude strength, yang digambarkan sebagai berikut:

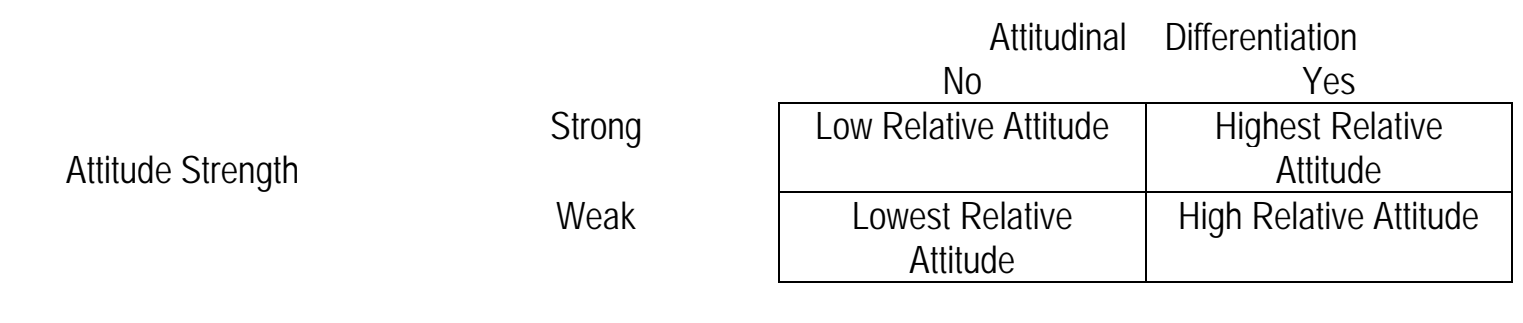

Sumber: Dick, A.S. \& K. Basu (1994)

\section{Gambar 1. Matriks Relative Attitude}

Secara konseptual, sikap terhadap obyek tertentu dapat positif atau negatif, tetapi dengan berfokus pada loyalitas konseptualisasi sikap lebih ditekankan pada sikap positif. Sikap positif ini berada pada kontinum, mulai dari lemah hingga kuat. Attitudinal differentiation adalah perbedaan persepsi individu terhadap obyek tertentu. Perbedaan persepsi juga berada pada kontinum, mulai dari tidak ada perbedaan hingga ada perbedaan. Penggabungan attitudinal differentiation dan attitude strength akan menghasilkan berbagai macam sikap relatif seperti terlihat dalam Gambar 1 (Dick dan Basu, 1994). Highest relative attitude dan high relative attitude berpeluang lebih tinggi untuk menciptakan repeat patronage (patronase pengulangan); yang pada akhirnya akan memperkuat hubungan sikap relatif dengan patronase pengulangan. Kekuatan hubungan sikap relatif dengan patronase pengulangan akan menentukan loyalitas seseorang.

Berdasarkan penjelasan di atas, sikap relatif sebenarnya mencerminkan dimensi attitudinal, sedangkan patronase pengulangan mencerminkan dimensi keperilakuan. Jadi, konseptualisasi loyalitas sebagai hubungan antara sikap relatif dengan patronase pengulangan akan memberikan penjelasan yang cukup pada 
pemasar tentang loyalitas pelanggan, dan pemasar dapat mengklasifikasikan pelanggan berdasarkan loyalitas dengan menggunakan matriks loyalitas (Dick dan Basu, 1994) sebagai berikut:

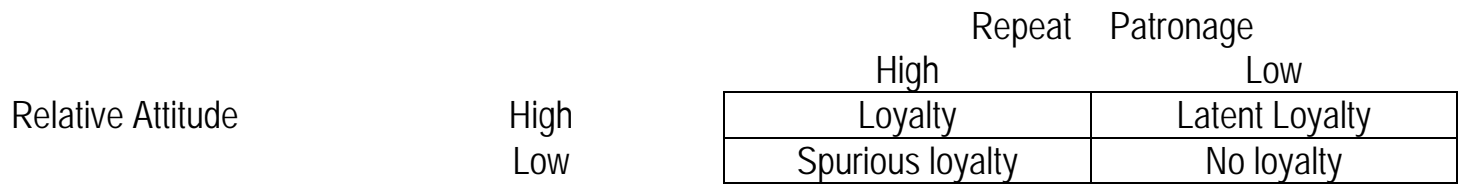

Sumber: Dick, A.S. \& K. Basu (1994)

\section{Gambar 2. Matriks Loyalitas}

Matriks loyalitas seperti terlihat dalam Gambar 2 menunjukkan bahwa loyalitas yang sebenarnya terjadi hanya pada saat patronase pengulangan dan sikap relatif tinggi. Jika sikap relatifnya rendah, maka dianggap sebagai spurious loyalty (loyalitas semu). Konsumen pada kondisi ini mungkin melakukan pembelian ulang hanya karena faktor-faktor situasional saja, misalnya keterbatasan dana, waktu, dll. Pelanggan dengan loyalitas semu tidak dapat diandalkan oleh pemasar. Pelanggan seperti ini memiliki kerentanan yang sangat tinggi untuk berpindah merek, terutama jika ada tawaran yang lebih menarik. Implikasinya, pemasar harus melakukan upaya-upaya untuk meningkatkan sikap relatif pelanggan terhadap merek pemasar, sehingga loyalitas semu dapat digeser menjadi loyalitas yang sesungguhnya. Sikap relatif yang tinggi, tetapi tidak diikuti dengan patronase pengulangan yang tinggi dianggap sebagai loyalitas yang bersifat laten (latent loyalty). Pelanggan dengan loyalitas laten sebenarnya memiliki niat untuk melakukan pembelian ulang terhadap merek pemasar, tetapi ada hambatan-hambatan yang menyebabkan niat tersebut tidak terlaksana. Implikasinya, pemasar harus mengamati, mencari, dan menghilangkan hal-hal yang menghambat niat pelanggan untuk membeli ulang. Dengan demikian, loyalitas laten dapat diubah menjadi loyalitas yang sesungguhnya oleh pemasar. Sikap relatif dan patronase pengulangan yang rendah menunjukkan no loyalty (tidak adanya loyalitas). Pelanggan yang tidak loyal tidak memiliki niat untuk membeli ulang merek pemasar. Implikasinya, pemasar harus berupaya memberikan insentif-insentif menarik sehingga pelanggan tertarik untuk mencoba merek pemasar. Dengan demikian, pemasar menggeser ketidakloyalan menjadi loyalitas semu (Dick dan Basu, 1994; Dharmmesta, 1999).

\section{TAHAPAN LOYALITAS}

Loyalitas akan berkembang mengikuti tiga tahap, yaitu tahap kognitif, afektif, dan konatif. Konsumen akan loyal lebih dulu pada aspek kognitifnya, kemudian pada aspek afektif, dan akhirnya pada aspek konatif (Oskamp, 1991 seperti dikutip oleh Dharmmesta, 1999). Pendapat tersebut sejajar dengan ilmu perilaku konsumen, bahwa konsumen akan melalui tahap learning $\rightarrow$ perception $\rightarrow$ attitude $\rightarrow$ behavior. Sikap sendiri terdiri dari 3 komponen, yaitu kognitif, afektif, dan konatif. Komponen kognitif berkaitan dengan proses pembelajaran konsumen, sedangkan komponen afektif berkaitan dengan sikap, dan konatif berkaitan dengan perilaku. Hal ini berarti sebelum mencapai aspek konatif, konsumen harus melewati terlebih dahulu aspek kognitif dan afektif.

Dharmmesta (1999) dan Oliver (1999) mengemukakan 4 tahap loyalitas dan kerentanan untuk berpindah merek sebagai berikut: 
Tabel 2. Empat Tahap Loyalitas

\begin{tabular}{|c|c|c|c|}
\hline Tahap & Basis Keloyalan & $\begin{array}{l}\text { Sumber Kerentanan Berpindah } \\
\text { Merek }\end{array}$ & $\begin{array}{l}\text { Alat Pemasaran untuk } \\
\text { Meningkatkan Loyalitas }\end{array}$ \\
\hline Kognitif & $\begin{array}{l}\text { Basis informasi yang dimiliki } \\
\text { hanya menunjuk pada satu merek } \\
\text { fokal yang dianggap lebih } \\
\text { superior dalam hal harga, } \\
\text { kualitas, fitur, dll dibanding merek } \\
\text { lain. }\end{array}$ & $\begin{array}{l}\text { Usaha persuasif pesaing; } \\
\text { keinginan mencari variasi, dan } \\
\text { mencoba merek lain. }\end{array}$ & $\begin{array}{l}\text { Komunikasi pemasaran harus } \\
\text { dapat meyakinkan konsumen } \\
\text { bahwa harga, dan kualitas } \\
\text { merek fokal lebih superior. }\end{array}$ \\
\hline Afektif & $\begin{array}{l}\text { Basis kepuasan dan kesukaan } \\
\text { terhadap merek fokal }\end{array}$ & $\begin{array}{l}\text { Ketidakpuasan, usaha persuasif } \\
\text { pesaing, dan keinginan mencari } \\
\text { variasi, mencoba merek lain. }\end{array}$ & $\begin{array}{l}\text { Meningkatkan kualitas } \\
\text { produk, serta } \\
\text { mempertahankan harga pada } \\
\text { kisaran yang relevan. }\end{array}$ \\
\hline Konatif & $\begin{array}{ll}\text { Basis komitmen } & \text { untuk } \\
\text { melanjutkan pembelian } & \text { merek } \\
\text { fokal di masa mendatang } & \end{array}$ & $\begin{array}{l}\text { Usaha persuasif pesaing, dan } \\
\text { keinginan mencari variasi, } \\
\text { mencoba merek lain. }\end{array}$ & $\begin{array}{l}\text { Memberikan reward pada } \\
\text { pelanggan yang setia, berupa } \\
\text { diskon khusus, member card, } \\
\text { dsb. }\end{array}$ \\
\hline Tindakan & $\begin{array}{l}\text { Basis komitmen, kesiapan untuk } \\
\text { mengatasi hambatan melakukan } \\
\text { tindakan pembelian }\end{array}$ & $\begin{array}{l}\text { Usaha persuasif pesaing, dan } \\
\text { keinginan mencari variasi, } \\
\text { mencoba merek lain. }\end{array}$ & $\begin{array}{l}\text { Memberikan reward pada } \\
\text { pelanggan yang setia, berupa } \\
\text { diskon khusus, member card, } \\
\text { dsb. }\end{array}$ \\
\hline
\end{tabular}

Sumber: diadaptasi dari Dharmmesta (1999) dan Oliver (1999)

\section{KEPUASAN SEBAGAI ANTESEDEN LOYALITAS?}

Seperti yang telah dikemukakan dalam tahapan loyalitas, terutama tahap afektif, bahwa salah satu anteseden loyalitas adalah kepuasan. Kepuasan sebagai anteseden loyalitas dibuktikan oleh studi yang dilakukan oleh Mittal dan Lassar (1998). Mittal dan Lassar mengelompokkan responden yang puas dan tidak puas, dan mengasosiasikan masing-masing kelompok dengan niat untuk berpindah merek. Hasilnya, semua anggota responden kelompok yang tidak puas menyatakan berniat untuk berpindah merek, sedangkan sebagian anggota kelompok yang puas (kisaran 19,5\% - 78,6\%) juga menyatakan beniat untuk berpindah merek (Mittal dan Lassar, 1998). Temuan Mittal dan Lassar (1998) mendukung studi sebelumnya yang dilakukan oleh Strauss dan Neuhaus (1997). Pendapat yang sama dikemukakan oleh Kandampully dan Suhartanto (2000); Hallowell (1996); Ruyter dan Bloemer (1999); Soderlund (1998) bahwa kepuasan mempunyai asosiasi positif dengan loyalitas, tetapi dengan catatan peningkatan kepuasan tidak selalu menghasilkan peningkatan loyalitas dalam derajat yang sama.

Oliver (1999) memberikan catatan bahwa fakta tersebut tidak kemudian berarti bahwa kepuasan tidak lagi punya peran untuk membentuk loyalitas pelanggan. Kepuasan tetap memiliki peran penting untuk membentuk loyalitas pelanggan, tetapi hanya sampai pada tahap afektif. Jadi, kepuasan hanya dapat membuat pelanggan loyal secara afektif, dan seperti terlihat pada Tabel 2, loyalitas afektif memiliki kerentanan untuk berpindah merek. Kepuasan saja tidak menjamin pelanggan untuk tetap loyal, karena Oliver (1999) memberikan argument bahwa ada consumer idiosyncrasies, ada aspek dari pelanggan yang kontra dengan keloyalan, seperti keinginan mencari variasi dan mencoba sesuatu yang baru.

Hubungan kepuasan dengan loyalitas yang tidak linier memberikan implikasi khusus bagi pemasar, antara lain: (1) Pemasar harus berupaya untuk membuat pelanggan puas, karena berbagai penelitian menemukan bahwa ada asosiasi positif antara kepuasan dengan loyalitas. Tetapi, pemasar hendaknya berhati-hati dalam menggunakan reward sebagai upaya untuk meningkatkan kepuasan pelanggan. Dowling dan Uncles seperti dikutip oleh O'Malley (1998) mengingatkan pemasar bahwa hubungan kepuasan dengan loyalitas tidak bersifat linier, akibatnya penggunaan promosi penjualan (potongan harga, hadiah, sampel produk, dII) sebagai salah satu bentuk reward dapat berbahaya. Bahayanya adalah pemasar mungkin akan terjebak pada lingkaran promosi, begitu insentif dihilangkan pemasar, konsumen juga tidak akan menemukan alasan untuk 
melakukan pembelian ulang; (2) Pemasar hendaknya tidak hanya mengukur kepuasan pelanggan, tetapi juga harus mengukur niat beli ulang pelanggan, dengan demikian pemasar dapat mengamati timbulnya gap (kesenjangan) antara kepuasan dengan loyalitas.

\section{KATEGORI DISLOYALTYINO-LOYALTY}

Berdasarkan uraian di atas, banyak sekali penelitian berfokus pada kepuasan, sebaliknya sangat sedikit penelitian tentang ketidakpuasan. Ketidakpuasan harus mendapat perhatian lebih besar, karena beberapa penelitian menunjukkan beberapa pelanggan yang tidak puas ternyata tetap setia, tidak berpindah merek. Johnston (1995) menyatakan dengan mengidentifikasi sejumlah faktor yang dianggap sebagai dissatisfiers dan satisfiers akan sangat membantu pemasar untuk mengurangi ketidakpuasan. Disloyalty (ketidakloyalan) juga tidak mendapat perhatian besar para peneliti dan pemasar. Pemasar dan peneliti perlu memberikan perhatian pada ketidakloyalan, terutama tentang faktor penyebab ketidakloyalan, apakah hanya disebabkan oleh ketidakpuasan, atau karena ada faktor lain. Dick dan Basu (1994) mengidentifikasikan ketidakloyalan sebagai kondisi dimana sikap relatif dan patronase pengulangan rendah, tetapi belum tentu negatif. Artinya, kategori ketidakloyalan mencakup pelanggan yang jarang membeli, pelanggan yang hilang, dan pelanggan potensial. Dengan mengidentifikasi alasan-alasan ketidakloyalan pelanggan, pemasar dapat mengambil tindakan-tindakan yang diperlukan untuk mengurangi ketidakloyalan pelanggan. Rowley dan Dawes (2000) mengungkap 3 alasan yang mendasari ketidakloyalan pelanggan:

1. Tidak ada minat terhadap obyek

2. Adanya orientasi negatif terhadap obyek.

3. Adanya orientasi positif terhadap obyek pesaing.

Rowley dan Dawes (2000) mengemukakan konsep ketidakloyalan atas dasar elemen keperilakuan dan attitudinal, dan membedakan kategori ketidakloyalan atas dasar perilaku dan sikap seperti terlihat dalam gambar 3.

\begin{tabular}{|c|c|c|}
\hline \multirow{4}{*}{ Attitude } & \multicolumn{2}{|c|}{ Behavior } \\
\hline & Inertial & Negative \\
\hline & Disengaged & Disenchanted \\
\hline & Disturbed & Disruptive \\
\hline
\end{tabular}

Sumber: Rowley, J., \& J. Dawes (2000), "Disloyalty: a closer look at non-loyals," Journal of Consumer Marketing, Vol 17, No. 6, pp. 541.

\section{Gambar 3. Matriks Disloyalty}

Matriks ketidakloyalan seperti terlihat dalam Gambar 3 tersebut di atas memberikan dua kategori untuk perilaku dan sikap, yaitu inertial dan negative. Inertial diasosiasikan dengan perilaku dan sikap yang relatif pasif, cenderung tidak suka mempengaruhi orang lain. Negative berhubungan dengan sikap negatif yang sangat kuat, atau perilaku yang berusaha menjatuhkan merek. Berdasarkan skala intensitas ketidakloyalannya, maka dapat dibuat urutan sebagai berikut:

\section{Disengaged $\rightarrow$ Disturbed $\rightarrow$ Disenchanted $\rightarrow$ Disruptive}

Disengaged loyal, lebih bersifat netral dan tidak punya interest (tendensi/kepentingan) tertentu. Individu yang termasuk kategori ini tidak pernah menjadi pelanggan perusahaan, dan memiliki karakteristik sebagai berikut:

- Tidak ada awareness (kesadaran) terhadap merek.

- Produk tidak relevan dengan kebutuhannya.

- Produk tidak masuk dalam area persepsi dan kemampuannya. 
Tetapi, tidak menutup kemungkinan individu yang termasuk kategori ini berubah menjadi loyal, misalnya karena status individu tersebut berubah, ataupun karena produk dan mereknya berubah. Implikasinya, pemasar harus meningkatkan awareness untuk merubah kelompok ini menjadi kelompok loyal.

Disturbed loyal, adalah pelanggan perusahaan yang sedang dalam masa keraguan tentang asumsi-asumsi terhadap merek yang selama ini diyakini. Kelompok ini mungkin punya negative feelings (perasaan negatif) tentang merek yang disebabkan oleh:

- Mengalami masalah dengan produk, mengalami pengalaman buruk dengan produk/jasa.

- Melihat perbandingan yang tidak menguntungkan dari merek yang selama ini mereka gunakan dengan merek lain.

- Promosi produk pesaing.

Meskipun, sikap kelompok ini terhadap merek negatif, kelompok ini masih mempertimbangkan untuk recommitment (membangun komitmen lagi) terhadap merek. Implikasinya, pemasar harus berupaya membangun kembali nilai-nilai positif merek, produk dan perusahaan, serta mengomunikasikannya kepada pelanggan. Dengan demikian, pelanggan dapat terpersuasi untuk melakukan re-commitment terhadap merek pemasar.

Disenchanted loyal, adalah pelanggan yang dahulu loyal, tetapi sekarang intensitas keloyalannya menurun. Hal ini ditunjukkan dengan tidak membeli merek tersebut lagi saat ini dan di masa mendatang. Walaupun demikian, kelompok ini masih mempunyai sikap yang netral terhadap merek. Sikap netral tersebut disebabkan oleh pengalaman positif di masa lalu. Disenchanted loyal muncul akibat:

- Pengalaman negatif dengan merek.

- Pengalaman positif dengan merek pesaing.

- Ketidaksesuaian persyaratan konsumen dengan produk.

Disenchanted loyal tidak lagi tertarik dengan strategi komunikasi nilai positif merek dari pemasar seperti halnya disturbed loyal. Implikasinya, pemasar harus melakukan perubahan radikal atas merek, dengan repositioning dan/atau inovasi.

Disruptive loyal, adalah pelanggan masa lalu perusahaan yang mempunyai sikap negatif yang kuat terhadap merek. Kelompok ini yang disebut 'teroris' oleh Jones dan Sasser (1995). Kelompok ini memelihara pandangan negatifnya terhadap merek dan suka mengomunikasikannya dengan pihak lain secara berlebihan. Sikap ini disebabkan oleh pengalaman masa lalu yang menyebabkan ketidakpuasan. Kelompok ini merepresentasikan kelompok yang benar-benar tidak loyal (true disloyalty) ditunjukkan dengan adanya hubungan yang kuat antara ketidakpuasan dengan termination of loyalty (pemutusan loyalitas) dan defection (tidak lagi menjadi pelanggan). Implikasinya, pemasar tidak dapat melakukan upaya-upaya untuk merubahnya, pemasar hanya dapat melakukan upaya-upaya untuk menolak dan/atau memperkecil timbulnya anggapan-anggapan negatif tentang merek.

Secara ringkas, empat kategori dan alat pemasaran yang dapat digunakan untuk mereduksi ketidakloyalan dapat dilihat pada Tabel 3 . 
Tabel 3. Empat Kategori Ketidakloyalan

\begin{tabular}{|c|c|c|c|}
\hline Kategori & Ciri-Ciri & Sumber Ketidakloyalan & $\begin{array}{c}\text { Alat Pemasaran untuk } \\
\text { Mereduksi Ketidakloyalan }\end{array}$ \\
\hline Disengaged & $\begin{array}{l}\text { Sifat netral, tidak pernah menjadi } \\
\text { pelanggan perusahaan. }\end{array}$ & $\begin{array}{l}\text { Tidak ada awareness terhadap } \\
\text { merek fokal. }\end{array}$ & $\begin{array}{l}\text { Komunikasi pemasaran } \\
\text { terintegrasi harus dilakukan } \\
\text { untuk meningkatkan } \\
\text { awareness terhadap merek } \\
\text { fokal }\end{array}$ \\
\hline Disturbed & $\begin{array}{l}\text { Memiliki keraguan atas keyakinan } \\
\text { dirinya terhadap merek fokal. }\end{array}$ & $\begin{array}{l}\text { Pengalaman buruk, } \\
\text { perbandingan dengan merek lain, } \\
\text { usaha persuasif pesaing. }\end{array}$ & $\begin{array}{l}\text { Komunikasi pemasaran } \\
\text { intensif untuk membangun } \\
\text { nilai poisitf merek fokal. }\end{array}$ \\
\hline Disenchanted & $\begin{array}{l}\text { Dahulu pelanggan loyal, tapi } \\
\text { sekarang tidak lagi, sikap netral. }\end{array}$ & $\begin{array}{l}\text { Pengalaman negatif dengan } \\
\text { merek fokal, pengalaman positif } \\
\text { dengan merek pesaing. }\end{array}$ & $\begin{array}{l}\text { Repositioning atau inovasi } \\
\text { produk }\end{array}$ \\
\hline Disruptive & $\begin{array}{l}\text { Dahulu pelanggan loyal, tapi } \\
\text { sekarang tidak lagi, sikap negatif. }\end{array}$ & $\begin{array}{l}\text { Pengalaman yang sangat negatif } \\
\text { dengan merek fokal, pengalaman } \\
\text { positif dengan merek pesaing. }\end{array}$ & $\begin{array}{l}\text { Komunikasi pemasaran untuk } \\
\text { memperkecil anggapan } \\
\text { negatif tentang merek fokal. }\end{array}$ \\
\hline
\end{tabular}

Sumber: diadaptasi dari Rowley dan Dawes (2000)

\section{1. Hubungan Kepuasan dengan Ketidakloyalan}

Argumen Oliver (1999) pada bagian sebelumnya dari tulisan ini, memberikan wacana bahwa kepuasan adalah anteseden loyalitas, sehingga dapat dikatakan bahwa tinggi rendahnya tingkat kepuasan pelanggan mempengaruhi tingkat keloyalannya. Jadi, dapat disimpulkan bahwa pelanggan yang memiliki tingkat kepuasan rendah, atau dapat dikatakan tidak puas cenderung untuk tidak loyal. Hal ini didukung oleh studi Mittal dan Lassar (1998) yang menemukan bahwa semua anggota responden kelompok yang tidak puas (100\%) menyatakan berniat untuk berpindah merek, sedangkan sebagian anggota kelompok yang puas (kisaran 19,5\% - 78,6\%) juga menyatakan beniat untuk berpindah merek.

\section{2. Hubungan Kategori Loyalitas dengan Kategori Ketidakloyalan}

Loyalitas laten mempunyai kecenderungan untuk menjadi tidak loyal, dalam kategori disengaged. Alasannya, pelanggan yang loyal secara laten jarang melakukan pembelian, sehingga pengalamannya dengan merek tersebut terbatas. Keterbatasan pengalaman tersebut mengakibatkan kecenderungan untuk memiliki sikap negatif terhadap merek rendah.

Loyalitas semu mempunyai kecenderungan untuk menjadi tidak loyal, dalam kategori disturbed atau disenchanted. Alasannya, loyalitas semu mempunyai sikap relatif yang rendah, tetapi patronase pengulangan tinggi. Artinya, pelanggan tidak mempunyai komitmen terhadap merek, hanya melakukan pembelian karena faktor situasional. Hal ini berarti bahwa pelanggan yang loyal secara semu cenderung akan berpindah merek jika terjadi perubahan situasi di sekitarnya.

Pelanggan yang loyal mempunyai banyak pengalaman dengan merek, komitmen, serta strong positive feelings (perasaan positif yang kuat) terhadap merek. Strong positive feelings yang dimiliki pelanggan loyal menyebabkan kecenderungan untuk bersikap negatif (strong negative feelings) terhadap merek semakin tinggi, terutama jika terjadi ketidakpuasan. Strong positive feelings dapat berubah menjadi strong negative feelings, sama seperti love-hate relationship.

\section{SIMPULAN}

Loyalitas pelanggan mempunyai peran stratejik dalam dunia pemasaran, karena loyalitas pelanggan menjadi dasar terciptanya profitabilitas, dan pembentukan keunggulan kompetitif yang berkelanjutan. Dinamika lingkungan mengakibatkan pergeseran pola perilaku konsumen. Pergeseran pola perilaku mengakibatkan peta loyalitas pelanggan berubah. Perubahan tersebut merupakan tantangan dan tugas berat pemasar dalam mengelola loyalitas pelanggan. 
Untuk dapat mengelola loyalitas pelanggan dengan baik, pemasar harus memiliki pemahaman yang komprehensif tentang loyalitas. Pemasar harus memberikan porsi perhatian yang sama besarnya terhadap loyalitas dan ketidakloyalan pelanggan. Pemahaman komprehensif tentang loyalitas akan memperdalam analisa pemasar tentang loyalitas pelanggan, sehingga pemasar dapat mengambil keputusan pemasaran yang tepat.

Kombinasi pendekatan attitudinal dan pendekatan keperilakuan akan menghasilkan definisi operasional yang memuaskan tentang loyalitas. Definisi operasional yang tepat membantu pemasar dan peneliti untuk menganalisa loyalitas lebih mendalam, sehingga pemasar dapat mengetahui anteseden-anteseden loyalitas, dapat mengklasifikasikan pelanggan berdasarkan loyalitas dan ketidakloyalannya, mengetahui hubungan loyalitas dan ketidakloyalan sehingga pemasar dapat mengantisipasi setiap kemungkinan yang terjadi dalam upaya pengembangan loyalitas pelanggan.

Pemasar harus memperhatikan komposisi pelanggan berdasarkan loyalitasnya. Jika pemasar bertujuan menciptakan pelanggan yang benar-benar loyal (true loyalty), maka pemasar harus berhati-hati dalam memberikan reward terhadap pelanggan yang loyal; terutama reward yang sifatnya jangka pendek hanya berupa pemotongan harga. Pemotongan harga yang dilakukan tanpa pertimbangan jelas akan membuat konsumen menjadi loyal hanya karena adanya insentif berupa pemotongan harga yang diberikan pemasar. Jika insentif tidak diberikan lagi, maka konsumen juga tidak akan loyal lagi (O'Malley, 1998).

\section{DAFTAR PUSTAKA}

Assael, H. (1998), Consumer Behavior and Marketing Action, $6^{\text {th }}$ ed. Cincinnati, OH: South-Western College Publishing.

Bowen, J.T., \& S.L. Chen. (2001), "The Relationship between Customer Loyalty and Customer Satisfaction", International Journal of Contemporary Hospitality Management, May, pp. 213-217.

Dick, A.S., \& K. Basu. (1994), "Customer Loyalty: Toward an Integrated Conceptual Framework", Journal of the Academy of Marketing Science, Vol. 22, No. 2, pp. 99-113.

Dharmmesta, B.S. (1994), "Perilaku Konsumen Indonesia Tahun 2000", Kelola Gadjah Mada University Business Review, No. 6/III/Mei, h. 83-93.

Dharmmesta, B.S. (1999), "Loyalitas Pelanggan: Sebuah Kajian Konseptual Sebagai Panduan Bagi Peneliti", Jurnal Ekonomi dan Bisnis Indonesia, Vol. 14, No. 3, h. 73-88.

Hallowell, R. (1996), "The Relationships of Customer Satisfaction, Customer Loyalty, and Profitability: an empirical study", International Journal of Service Industry Management, Vol. 7, No. 4, pp. 27-42.

Jones, T.O., \& W.E. Sasser. (1995), "Why Satisfied Customers Defect", Harvard Business Review, NovemberDecember, pp. 88-99.

Johnston, R. (1995), "The determinants of service quality: satisfiers and dissatisfiers", International Journal of Service Industry Management, Vol. 6, No. 5, pp. 53-71.

Kandampully, J., \& D. Suhartanto. (2000), "Customer Loyalty in The Hotel Industry: The Role of Customer Satisfaction and Image", International Journal of Contemporary Hospitality Management, June, pp. 346-351.

Lau, G.T., \& S.H. Lee (1999), "Consumers' Trust in a Brand and the Link to Brand Loyalty", Journal of Market Focused Management, No. 4, pp. 341-370.

Mittal, B., \& W.M. Lassar (1998), "Why do customers switch? The dynamics of satisfaction versus loyalty", The Journal of Services Marketing, Vol. 12, No. 3, pp. 177-194. 
Oliver, R.L. (1999) "Whence Consumer Loyalty?," Journal of Marketing, Vol. 63, pp. 33-44.

O’Malley, L. (1998), "Can loyalty schemes really build loyalty?", Marketing Intelligence \& Planning, January, pp. 47-55.

Rowley, J., \& J. Dawes. (2000), "Disloyalty: a closer look at non-loyals", Journal of Consumer Marketing, Vol. 17, No. 6, pp. 538-549.

Rowley, J., \& J. Dawes. (1999), "Customer Loyalty - a Relevant Concept for Libraries?", Library Management, Vol. 20, No.6, pp. 345-351.

Ruyter, K., \& J. Bloemer. (1999), "Customer Loyalty in Extended Service Settings", International Journal of Service Industry Management, Vol. 10, No. 3, pp. 320-336.

Soderlund, M. (1998), "Customer satisfaction and its consequences on customer behavior revisited", International Journal of Service Industries Management, Vo. 9, No.2, pp. 169-188.

Strauss, B. and Neuhaus, P. (1997), "The qualitative satisfaction model", International Journal of Services Industries Management, Vol. 8, No.3, pp. 236-249. 